\title{
Board Subcommittees: If Not, Why Not?
}

\author{
Tek Lama ${ }^{1}$ \\ ${ }^{1}$ College of Business, Victoria University, Sydney, Australia \\ Correspondence: Dr Tek Lama, College of Business, Victoria University, 545 Kent St., Sydney, NSW 2000, Australia. \\ Tel: 61-2-9283-3601. E-mail: tek.lama@vu.edu.au
}

Received: July 15, 2014

Accepted: August 2, 2014

Online Published: August 5, 2014

doi:10.5430/afr.v3n3p117

URL: http://dx.doi.org/10.5430/afr.v3n3p117

\begin{abstract}
This study examines factors that may influence a company's decision to comply or (depart) from certain ASX recommended governance of best practice under the ASXCGC's 'if not, why not' corporate governance framework. In particular, it investigates 2 recommended practices relating to the board subcommittees and whether any particular factors determine a company's decision to comply with those practices. The investigation of 268 Australian Stock Exchange (ASX) listed companies using panel data between 2004 and 2007 provides statistically convincing evidence that certain factors are likely to influence the company's responses with respect to board subcommittee related best practices. This finding is consistent with the underlying philosophy of the 'if not, why not' corporate governance framework and generally accepted view that when it comes to corporate governance; one-size-does-not-fit-all.
\end{abstract}

Keywords: Best practice recommendations, 'If not, why not', Corporate governance, Australian stock exchange, Comply or explain

\section{Introduction}

A company's corporate governance is viewed as a multi-dimensional construct consisting of many systems and processes covering a wide range of components. More specifically, it is the process of supervision and control (ASXCGC, 2003; Cadbury, 1992). While the company board sits at the core of the process, it needs other mechanisms of support to ensure efficient governance by examining a particular aspect of governance. Board subcommittees are increasingly considered as part of such mechanisms. Hence, there is growing expectation that a company's corporate governance structure will include certain board subcommittees, particularly key ones such as Audit, Remuneration and Nomination committees.

The 'Principles of Good Corporate Governance and Best Practice Recommendations' introduced in 2003 by the Australian Stock Exchange Corporate Governance Council (ASXCGC) also recommends listed companies to establish such board subcommittees. In particular, this governance framework document asserts that board subcommittees can be more efficient mechanism than the full board for focussing the company on particular issues; and it is particularly so for larger companies (ASXCGC, 2003).

This government framework, which Du-Plessis, McConvill, \& Bagaric (2005) described as the most significant government reform in Australia, recommends 26 recommendations, of which 3 of them are board subcommittee related. The framework views these recommendations as the governance of best practices. However, this governance framework contains a 'if not, why not' clause under which companies had the option either to follow the recommended best practices or provide reasons why the departure was necessary. That means, companies are allowed to choose not to have such committees as long as they justify for doing so.

The flexibility to depart from a recommendation or recommendations inherent in the framework is consistent with the generally accepted view that corporate governance is not a one-size-fits-all concept (Arcot, Bruno, \& Faure-Grimaud, 2010; La Porta, Lopez-de-silanes, Shleifer \& Vishny, 2002). There is a growing perception that 'one size fit all' approach to governance creates a burden for smaller companies by placing them on an unequal footing against their bigger counterparts. PraicewaterhouseCooper (2012) noted that it is unduly restrictive on business and makes a country a less attractive place of business for foreign companies.

Karen Hamilton, Chairperson of the ASXCGC, opined that flexible governance regulation was even more important in the case of Australia as the Australian market is dominated by smaller companies, in contrast to the US where 
large companies dominate the market (Hamilton, 2003). She suggested that this consideration was the determining factor behind the ASXCGC's decision to opt for disclosure-based framework premised on the 'if not, why not' concept. Nedelchev (2013) argues that this form of governance regulation allows companies to have the right balance between the costs and benefits considering all the circumstances, and therefore enables them to tailor their governance structure to meet their actual operational requirements.

It is worth noting that the 'if not, why not' form of governance is not a new concept. This was very similar to the concept of 'comply or explain' introduced by the United Kingdom (UK) Cadbury Committee in 1992, in response to a series of corporate scandals in that country (Cadbury, 1992). Today, this model of regulating governance practices of listed companies has been adopted by many countries, and has virtually become the benchmark framework around the world (Wang \& Ong, 2005).

Although 'comply or explain' (known as 'if not, why not?' in Australia) approach to corporate governance is gaining popularity around the world as the preferred mode of regulation for listed companies, Seidl, Sanderson, and Roberts (2009) document the lack of research on this. They argue that very little is known about the way that the comply-or-explain reporting mechanism functions in practice. They make this assessment in the UK context where this system of governance has been in operation since 1992. This problem is likely to be even more common in countries like Australia which introduced this model of governance regulation relatively recently.

This paper constitutes an important research effort in this apparently overlooked but highly important corporate governance framework. In particular, it investigates how listed companies use the flexibility inherent in this framework in structuring their corporate governance mechanism. This study examines companies' compliance decision with respect to two board subcommittee-related recommendations - (i) 4.2: audit committee and (ii) 9.2 remuneration committee. During the data collection process, it became apparent that many companies seemed to delegate the functions of the nomination committee to the remuneration committee. Accordingly, nomination committee is not considered for investigation in this study. The underlying objective of this study is to investigate whether companies use certain considerations (e.g. size, profitability etc.) in deciding whether or not to adopt these recommended practices. It is argued that the findings to this important issue are vital for assessment of the governance framework, particularly with respect to their future prospects and direction.

The paper is laid out as follows. Section 2 reviews the existing body of research literatures on the 'if not, why not' approach to governance, and this will be followed by a construction of research postulations in Section 3. Section 4 outlines research methodology whereas Section 5 reports and discusses the research findings. The final section concludes, as well acknowledging limitations and suggesting future research opportunities.

\section{Review of the relevant extant studies}

As noted by Seidl, Sanderson, and Roberts (2009), research on the 'if not, why not' (referred as 'comply or explain' in most other jurisdictions) is lacking. The lack of research is likely to be even more prevalent in countries like Australia which introduced this system of governance more recently. Further to that, the focus of studies to date on 'comply or explain' tended to be on assessing the level of compliance with the recommended best practices. This implies that research scholars are using the level of compliance as a proxy for good governance. For example, ASX investigated Australian listed companies' reporting practice under the 'if not why not?' reporting regime each year since 2004; entirely focussing on their level of compliance with recommended practices (ASX, 2005; 2006; 2007). KPMG also conducted surveys in the initial stages of the introduction of the 'if not, why not' framework (KPMG, 2004; 2005). They too have focussed on the level of compliance only.

Studies undertaken in other jurisdictions also appear to have a similar focus. Arcot and Bruno (2006) investigated governance reporting practices of 245 non-financial companies under the UK's 'comply or explain' governance framework, and reported an increase in the rates of compliance. Seidl, Sanderson, and Roberts (2009) analysed the compliance statements of 260 companies in Germany and the UK (130 from each country) in annual reports published in 2006 and reported that compliance levels in both countries dropped as company size decreased. Akkermans et al. (2007) examined governance reporting practice of 150 Dutch listed companies under the Netherland's Tabaksblat Code and reported a high level of compliance with the code.

The focus on compliance only could have an implication. In particular, it could lead companies and investors alike to view the rate of compliance as a proxy of good governance. In other words, this could suggest that companies must follow each and every recommended practice and failure to do so could mean they are deemed to having inferior governance mechanism. This perception contradicts the core concept of the 'if not, why not' model of governance and thus undermines its intended objectivity. This has been acknowledged by ASX's Implementation Review Group 
(IRG) which noted that some companies have spoken of the need to 'conform to' or 'comply with' the recommendation (IRG, 2004, p.2). This has also been the concern expressed by a few research scholars (Zadkovich, 2007; Fleming, 2003).

Some researchers also examined the 'comply or explain' from different angle. Brown and Gorgens (2009) examined whether levels of compliance with the recommended practices is associated with the levels of company performance. They reported that the top 300 ASX listed companies that demonstrated greater compliance with the ASXCGC recommended best practices outperformed their less compliant counterparts. However, MacNeil and Li (2006) reported that their survey of FTSE 100 serial non-compliers suggests that there is in fact a strong link between share price performance and investors' tolerance of non-compliance with the UK Combined Code. They concluded that the effect of 'comply or explain' is to distance shareholders from compliance decision and to strengthen the role of the Board by comparison with the operation of a default rule. That means the 'comply or explain' does not appear to deliver a role for the market as suggested by Steeno (2006).

It seems that no study has investigated why companies follow or depart from the recommended best practice. In particular, whether certain factors specific to a company influence its compliance decision is relatively unknown. This is a significant knowledge gap in the research record given the objective of the 'if not, why not' approach to governance is to allow companies to make informed assessments as to which recommended practices are important for them or not and structure their corporate governance practices and reporting accordingly.

Having board subcommittee, as part of a company's governance mechanism, has both benefits and disadvantages. Benefits include enhanced efficiency in the company's governance through detailed and expert examination of particular issue (ASXCGC, 2003). Research also document the board subcommittee especially the audit committee associated with fewer errors, irregularities (McMullen, 1996) and less likelihood of overstating earnings (DeFond \& Jiambalvo, 1991). On the other hand, establishing and maintaining subcommittee incurs significant additional costs. It is also argued that, to the extent that the subcommittee functions in the place of the full board, the company loses the benefit of the full range of business and leadership experience represented on the board (Lumsden, 2004). It is therefore assumed that these two ASXCGC recommended practices are reasonable pilot candidates for investigating this research issue.

\section{Construction of the research postulations}

The underlying research question being investigated in this research paper is what appears to influence a company's decision to comply with each of the 2 board subcommittee related best practice recommendations. This question is important, as the 'if not, why not?' framework allows departure provided any departure is disclosed and explained (ASXCGC, 2003).

All else being equal, one would expect that companies follow a least-cost approach to compliance with regulation not complying unless it is in companies' best interest to do so. This flexibility to opt out is the key feature underpinning the 'if not, why not' model of corporate governance. The cost associated with achieving compliance is financial one, while that of non-compliance is, in the first instance, reputational, but has a consequent capacity to become financial. Therefore, companies which face a relatively high cost for non-compliance are likely to comply while those facing relatively low costs are less likely to comply. This very assumption underpins the 6 research postulations being developed in this section.

It could be assumed that bigger companies are more likely to adopt governance mechanism that is perceived by investors and alike credible. ASXCGC (2003) clearly specifies that, board subcommittee can be more efficient mechanism for detailed examination of particular issues such as verifying and safeguarding the integrity of the company's financial reporting or appropriateness of remuneration policies; particularly for larger companies. In fact, disparity in company sizes due the unique nature of Australian market was the reasons behind the ASCCGG's decision to opt for disclosure-based framework premised on the 'if not, why not' concept (Hamilton, 2003). Further to that, compliance is costly (Krishnan, Krishna, \& Zhang, 2008; D'Aquila, 2004) and complying with board subcommittee-related best practices in particular is both costly and logistically challenging. Larger companies tend to have a greater level of access to the resources needed to meet these compliance challenges.

In a company where the largest owners have a significantly large shareholding to exert significant control, the reputational cost of non-compliance diminishes. These shareholders may place a higher value on making the company's governance less transparent to minority shareholders. This means companies with such shareholding structure may choose not to have board subcommittees. This study will use the percentage of shares held collectively by the Top-twenty shareholders as proxy measure of ownership concentration. 
Company's leverage is generally viewed as a monitoring mechanism. The higher a company's level of debt is, the greater will be the performance pressure on the firm's management to meet interest and repayment obligations (Jensen, 1986). High leverage also implies greater risk exposure as it amplifies losses and a levered company may face insolvency during a business downturn due to lack of liquidity. It may therefore be important for a highly levered company to demonstrate to investors and creditors that it has a credible corporate governance system, in the context of which, the decision to take on high leverage is strategic and in their best interest. One of the ways the company can do this is by having a credible governance structure that includes various board subcommittees to support the full board and enhance governance efficiency of the company.

MacNeil and Li (2006) speculate that investors may routinely adopt financial performance as a proxy for judging the merits of non-compliance and be prepared to tolerate non-compliance, to the extent, that the company performs well. It is possible the company use this investor tolerance as an excuse for opting out from various recommended best practices which may include board subcommittees.

Company's corporate governance mechanism evolves over the time. The longer the company has been in operation, the greater becomes the likelihood of it having a well-structured corporate governance system. This could also mean that older companies are more conscious of the reputational value associated with corporate governance and therefore are inclined to opt for a better governance system in terms of a well-structured board with appropriate supporting board subcommittees.

Coffee (2002) argues that companies may choose to cross-list for two reasons - (i) to obtain additional pools of equity and (ii) to commit themselves to higher standards of corporate governance. Consistent with this argument, Arcot and Bruno (2006) report a significant difference between the governance practices of cross-listed and non-cross-listed UK companies. In terms of companies following a least-cost approach, the cost of compliance with respect to the best practice recommendations become negligible if the cost is already being met with respect to basically the same recommendations in force in overseas jurisdictions. For this reasons, dual or multi listed companies are likely to have well-structured corporate governance that complies with virtually all recommended governance of best practices. The following 6 research postulates are specified and tested to answer the research case made in this study:

1. The likelihood of the company complying with the board subcommittee-related recommendation increases with an increase in its size.

2. The likelihood of a company complying with the board subcommittee-related recommendation decreases with increased ownership control proxied by the percentage of shares held by the top twenty shareholders

3. The likelihood of the company complying with the board subcommittee-related recommendation increases with an increase in the level of leverage.

4. The likelihood of the company complying with the board subcommittee-related recommendation decreases with an increase in its profitability.

5. The likelihood of the company complying with the board subcommittee -related recommendation increases with an increase in its age.

6. The likelihood of the company complying with the board subcommittee-related recommendation is greater for companies which also have a secondary listing.

\section{Methodology}

This study uses panel data provided by a random sample of 268 companies listed on the ASX during the reporting periods ending $2004-2007$. The sample includes only companies remained listed throughout the study period. The timespan is chosen to limit the study to the lifespan of the first edition of the ASX best practice recommendations introduced in 2003 (Note 1). Corporate governance data was collected from the Aspect Huntly Annual Report Online and financial data was collected from Aspect Huntly FinAnalysis Database.

For all 6 research postulations, the analysis is performed with a binary logistic regression in which the dependent variable is compliance (i.e. adoption) with 2 board subcommittee-related recommendations. This variable is binary and therefore takes the value of ' 1 ' if the company is compliant and ' 0 ' otherwise. Six variables that are considered company specific are included as predictor (independent) variables in the data analysis model. They are defined and approximated as shown in Table 1 below. 
Table 1. Variable description and measurement

\begin{tabular}{|c|c|}
\hline Variables & Description and Measurement \\
\hline Size & $\begin{array}{l}\text { The natural log of total assets of the company as of its reporting date, based on the } \\
\text { balance sheet figure in millions. }\end{array}$ \\
\hline $\begin{array}{l}\text { Top-twenty } \\
\text { shareholding }\end{array}$ & $\begin{array}{l}\text { The percentage of common shares held by the Top-twenty shareholders, irrespective of } \\
\text { whether these shareholders are individuals or institutional shareholders. It is a measure of } \\
\text { how closely held the firm is. }\end{array}$ \\
\hline Leverage & $\begin{array}{l}\text { The Company's level of leverage which is calculated by dividing the company's total } \\
\text { debt by its total assets. }\end{array}$ \\
\hline Profitability & $\begin{array}{l}\text { Profitability is represented by the company's return on assets as calculated by dividing } \\
\text { net profit after tax by its total assets. }\end{array}$ \\
\hline Age & $\begin{array}{l}\text { Number of years listed on the ASX, irrespective of whether cross-listed or not, surrogates } \\
\text { this variable. }\end{array}$ \\
\hline Cross-listing & $\begin{array}{l}\text { Binary variable; coded ' } 1 \text { ' if the company is also listed on an overseas stock exchange } \\
\text { and ' } 0 \text { ' otherwise. }\end{array}$ \\
\hline
\end{tabular}

The data were screened prior to the analysis to minimise the effect of outliers and unacceptably high multicollinearity (Note 2). Since Logit Regression does not make any assumption concerning the distribution of predictor variables (Pallant, 2007), testing for normality was not considered necessary.

The Binary Logistic Regression model was chosen because it is most useful when modelling an event probability for a categorical response variable with two outcomes (Kristjanson et al., 2007). It directly estimates the probability of an event or state occurring. Consistent with the model demonstrated by Dominguez-Almendros, Benitez-Parejo, and Gonzalez-Ramirez (2011), the model in which there are $\mathrm{k}$ independent variables $\left(X_{1}, X_{2}, \ldots X_{\mathrm{k}}\right)$ is specified as:

$$
y=\ln \left[\frac{\rho}{1-\rho}\right]=\beta_{0}+\beta_{1} \chi_{1}+B_{2} \chi_{2}+\ldots+\beta_{k} \chi_{k}+e
$$

In Equation 1, $\mathrm{y}$ is the binary dependent variable, $X_{\mathrm{k}}$ signifies the $\mathrm{k}^{\text {th }}$ predictor variable (in this case there are six ) and $\beta_{\mathrm{k}}$ is the coefficient of predictor variable $\mathrm{k}$. The residual term ' $\mathrm{e}$ ' captures the variability not explained in the model.

In terms of probability, Equation 1 can be rewritten as follows:

$$
\rho=\frac{1}{1+\exp -\left(\beta_{0}+\beta_{1} \chi_{1}+\ldots+\beta_{k} \chi_{k}\right.}+e
$$

The objective here is to relate $\rho$, the true proportion of companies presenting certain characteristic (e.g. comply with a particular recommendation) to the value of any explanatory variable $X_{\mathrm{k}}$ as a possible determinant factor. The important aspect of the logistic regression model is that variables can be jointly analysed with a view to examining how they relate to the occurrence or non-occurrence of the state of interest (Dominguez-Almendros, Benitez-Parejo, \& Gonzalez-Ramirez, 2011), which in the current study is compliance (or non-compliance) with 2 board subcommittee-related recommendations. The data was analysed using the computer data analysis application, SPSS.

\section{Findings}

First, summary statistics of predictor variables used in the analysis are presented. Summary statistics of continuous predictor variables are shown in Table 2. The underlying data are panel data from 2004 to 2007. 
Table 2. Summary statistics of continuous variables

\begin{tabular}{lcccc}
\hline Variables & Mean & Min & Max & Std. deviation \\
\hline Size (total assets \$) & 3678.87 & 0.04 & $564,634.00$ & $35,071.95$ \\
Top-twenty shareholding & 0.64 & 0.07 & 1.00 & 0.20 \\
Leverage & 0.37 & 0.00 & 1.37 & 0.29 \\
Profitability & -0.05 & -0.61 & 0.55 & 0.25 \\
Age & 15.21 & 2.00 & 46.00 & 10.09
\end{tabular}

Description: Total assets which proxy 'company size' is expressed in dollar in million. The Top-twenty shareholding is used as a measure of a company's ownership concentration. Leverage is represented by ratio of total liability-to-total assets. Profitability is calculated dividing net profit after tax by total assets whereas age is actual number of years the company has been listed on the Stock Exchange. The minimum age of 2 years reported in the table is the age in 2004, the first year of the sample period

The mean value of sample companies' assets was $\$ 3678.87$ million and assets of the sample companies ranges from $\$ 0.04$ million to $\$ 5064634.00$ million, suggesting significantly diverse sample. Top-twenty shareholding ranges from $0.07(7 \%)$ to $1.00(100 \%)$. That means at least one sample company is entirely owned by the Top-twenty shareholders. On average however, the Top-twenty shareholders own 0.64 (64\%) of the sample companies. The maximum leverage of 1.37 indicates that the samples include at least one company with negative equity. The mean of the profitability is also negative. The range of the company age is from 2 years in 2004 to 46 years in 2007 . This also suggests that sample includes companies with significantly diverse ages. This diverse sample is considered appropriate given research intention of this study which is to determine possible influence of certain variables on the company's compliance (i.e. governance decision). Cross listing which is a dichotomous variable is not shown in Table 2. However, the median value of this variable turns out to be zero indicating that majority of the companies was not cross-listed.

Table 3 shows the results of two binomial logistic regressions performed with respect to the nature of compliance with board subcommittee-related ASX recommended best practices. The dependent variables in the two regressions were compliance (or not) with (i) 4.2 - The board should establish an audit committee, and (ii) 9.2 - The board should establish a remuneration committee.

Table 3. Binary logistic regression results on ASX guidelines governing board subcommittee (4.2 \& 9.2)

\begin{tabular}{|c|c|c|c|c|c|c|c|c|}
\hline & \multicolumn{4}{|c|}{ 4.2: Audit Committee } & \multicolumn{4}{|c|}{ 9.2: Remuneration Committee } \\
\hline & B & S.E. & Wald & $\begin{array}{l}\text { Odds } \\
\text { Ratio }\end{array}$ & $\mathrm{B}$ & S.E. & Wald & $\begin{array}{l}\text { Odds } \\
\text { Ratio }\end{array}$ \\
\hline Constant & $-1.28 * * *$ & 0.34 & 14.07 & & $-1.91 * * *$ & 0.30 & 41.57 & \\
\hline Size (TA) & $0.60 * * *$ & 0.06 & 115.84 & 1.82 & $0.51^{* * *}$ & 0.05 & 125.69 & 1.67 \\
\hline Top-twenty holdings & 0.50 & 0.40 & 1.54 & 1.64 & 0.45 & 0.35 & 1.65 & 1.56 \\
\hline Leverage & $1.14 * * *$ & 0.28 & 16.06 & 3.12 & $0.90^{* * *}$ & 0.26 & 12.04 & 2.45 \\
\hline Profitability & 0.35 & 0.34 & 1.05 & 1.42 & -0.63 & 0.33 & 3.67 & 0.54 \\
\hline Age & $-0.02 * *$ & 0.01 & 5.43 & 0.98 & -0.01 & 0.01 & 0.88 & 0.99 \\
\hline Cross Listing & $-0.65 * * *$ & 0.25 & 6.82 & 0.52 & $-0.48^{* *}$ & 0.23 & 4.53 & 0.62 \\
\hline \multicolumn{9}{|c|}{ Test for overall model evaluation and goodness of fit } \\
\hline $\begin{array}{lll}\text { Omnibus } & \text { Test } \\
\text { Model } \chi^{2} & & \end{array}$ & \multicolumn{4}{|c|}{$299.52 * * *$} & \multicolumn{4}{|c|}{$257.32 * * *$} \\
\hline Nagelkerke $\mathrm{R}^{2}$ & \multicolumn{4}{|c|}{0.35} & \multicolumn{4}{|c|}{0.29} \\
\hline
\end{tabular}

Description: $* * *, * *$ and $*$ indicate significance levels of $1 \%, 5 \%$ and $10 \%$ respectively. 
The overall model is statistically significant in the case of both analyse models as demonstrated by the significant Omnibus Test of Model coefficients $\left(\chi^{2}\right)$. The Nagelkerke $\mathrm{R}^{2}$, a measure of goodness-of-fit, is 0.35 and 0.29 respectively, indicating both regression models are robust.

The relationship between company size and the likelihood of a company having board subcommittee is as anticipated; and the relationship is statistically significant in both cases. With respect to recommended practice 4.2, controlling for all other variables in the model, a unit increase in size; the model estimates that the logit (i.e. $\log$ odds) of complying with best practice 4.2 increases by 0.60 units. In the case of recommendation 9.2 , an increase estimated by the regression model of each unit of increase in the company's asset is 0.51 units. The equivalent odds ratio (1.82) is more easily interpreted: a unit increase in size increases the probability of complying with recommended practice by 82 percent. In case of recommendation 9.2 this probability is 67 percent. Therefore, research postulation 1 is supported.

Insignificant coefficient $(\beta)$ of the ownership concentration as measured by the Top-twenty shareholding means that the research postulation 2 is not supported. In fact, the opposite seems to the case as suggested by positive coefficient value - bigger the shareholdings of the Top-twenty shareholders, higher the likelihood of a company having board subcommittees.

The coefficient of leverage is positive and statistically significant in both cases. This provides evidence that high levered companies are likely to demonstrate high quality governance system by complying with appropriate best practice recommendations possibly in order to dampen perceived risk and maintain a high leverage ratio without affecting its ability to borrow. In fact, the results suggest that, controlling for other predictor variables in the model, a unit increase in leverage, model estimates that the logit of complying with recommended practice 4.2 increases by 1.14 units. In case of recommended practice 9.2, model estimates of log odds of complying increases by 0.90 units. Hence, the result is consistent with the research postulation 3.

With respect to profitability variable, the findings are mixed. The coefficient $(\beta)$ for the recommendation 4.2 is positive while for recommendation 9.2, it is negative. Both coefficients, however, are statistically insignificant. Research postulation 4 is thus not supported.

The coefficient of age variable is significant only in case of recommendation 4.2. However the, direction of the relationship is negative in both cases. That means the finding is inconsistent with the assumption made in the research postulation 5. This is also the case with respect to cross-listing variable as suggested by negative and statistically significant coefficient.

\subsection{Discussion}

Two variables 'size' and 'leverage' seem to influence greatly on a company's compliance decision with respect to board-subcommittee-related recommendation. In case of size, good governance structure is financially feasible and important in adding reputational value. In fact, the framework itself clearly stipulates that board subcommittees are more efficient for larger companies (ASXCGC 2003). The company's leverage provides a reasonable proxy of that particular company's risk. In this sense, higher leverage is generally perceived as more risky although this perception may vary between companies. Regardless, continued investors' and lenders' support is crucial for both the company's ability to borrow and in determining the terms of borrowing. Good and credible corporate governance is likely to help the company to dampen the perceived risk because of relatively high level of leverage. The result certainly seems to support this argument. However, the ownership concentration, as measured by the percentage of holing by the Top-twenty shareholders, seems to have no effect on the company's compliance decision.

The study by MacNeil and Li (2006) documented that more profitable companies can afford to be less compliant because investors appear more tolerant of non-compliance against profitable companies. It is generally accepted view that investors point the finger to the managements and its governance approach only when the company starts to show signs of financial distress. However, the finding of this study does not seem to support MacNeil and Li's research findings.

There is no evidence to suggest that older companies and companies that are listed on multiple stock exchanges will be more compliant with the recommended practices. In that sense, the finding does not support Coffee (2002) suggestion that cross-listed companies seek to have a credible governance structure and thus likely to comply with recommended best practice of governance. In fact, the results suggest that, as company decide to list overseas, its likelihood of complying with board subcommittee-related recommended practice decreases. Only possible explanation for this is that the company has already complied with the overseas compliance requirements and hence feel unnecessarily to comply with Australian recommendations. The result also gives no evidence to the argument 
that older companies are more likely to comply as they understand the reputational value of the good governance. It may well be the fact that, longer it operates and especially it operates without any issues, the need for additional governance measure may become less relevant. It may make better sense to quote the commonly used cliché - if it is not broken, do not fix it.

This study seems to suggest that the 'if not, why not' concept of governance is achieving its desired outcome. The findings of this study appears to show that Australian listed companies are adopting those recommended practices that they feel desirable and depart from some other practices they believe may not serve their operational interest; taking into account of various factors. However, what justification do they give when they decide not to comply, and whether they give adequate and convincing justification, is completely another matter and subject to another study.

\section{Conclusion, limitation and future research}

This study examined whether companies simply follow the ASX recommended best practices particularly in relation to board subcommittee-related best practice (i.e. $4.2 \&$ 9.2) or take into account various factors in making compliance decisions. The results provide statistically robust evidence, in some cases, that they do. The findings are consistent with underlying principle of the ASXCGC's 'if not, why not?' approach to governance. Furthermore, the results support the generally accepted view that companies differ in size and diversity and thus have different governance needs. To rephrase, one-size does-not-fit-all.

I now acknowledge some caveats pertinent to the findings of this study. Only six various attributes have been used to test the company's response with respect to adopting (or departing) from board subcommittee-related best practice. It is possible that other attributes not included in the model might also be important. The observed results have not been subjected to a robustness test. In addition, research in social science always tends to suffer from the use of personal judgement in estimating and approximating variables and this certainly applies to this study as well.

This study now outlines a number of possible future research avenues. For example, the ASXCGC released significantly revised principles ( $2^{\text {nd }}$ edition) in 2007 which became effective from the financial period ending 2008. The current study can be extended using the companies' compliance data under this revised regime. The current study did not include much of the period of the Global Financial Crisis which started towards the end of 2007. So, examining the effectiveness of the ASX principles during the Global Financial Crisis could be another interesting future research proposition. More importantly, the 'if not, why not' governance is a two-pillar regulatory framework of which compliance is only one pillar. The other is the requirement for an explanation given for non-compliance. In order to get an insight into the full working and operation of this framework, it is equally important that explanation pillar too is examined. This offers another interesting future research possibility.

\section{References}

Akkermans, D., Ees, H., Hermes, N., Hooghiemstra, R., Laan, G.V., Postma, T., \& Witteloostuijn, A. (2007). Corporate governance in the Netherlands: an overview of the application of the Tabaksblat Code in 2004. Corporate Governance, 15(6), 1106-1118. http://dx.doi.org/10.1111/j.1467-8683.2007.00634.x

Arcot, S, V., Bruno, V., \& Faure-Grimaud, A. (2010). Corporate governance in the UK: is the comply or explain approach working? International Review of Law and Economics, 30(2), 193-201. http://dx.doi.org/10.1016/j.irle.2010.03.002

Arcot, S. \& Bruno V. (2006) In letter but not in spirit: an analysis of corporate governance in the UK. Working Paper no.031. Retrieved $\quad$ October $22, \quad 2010, \quad$ from http://www2.lse.ac.uk/fmg/research/RICAFE/pdf/RICAFE2-WP31-Arcot.pdf.

Australian Stock Exchange (2005). Analysis of Corporate Governance Practices in 2004 Annual Reports. Retrieved September 20, 2010, from http://www.asx.com.au/documents/about/analysis_of_cg_practice_disclosure_may_16_2005.pdf.

Australian Stock Exchange (2006). 2005 Analysis of Corporate Governance Practice Disclosure. Retrieved September 20, 2010, from http://www.asx.com.au/documents/about/2005_analysis_cg_practice_disclosure.pdf.

Australian Stock Exchange (2007). Analysis of Corporate Governance Practice Disclosure in 2006 Annual Reports. Retrieved September 20, 2010, from http://www.asx.com.au/documents/about/2006_corporate_governance_practice_disclosure.pd.

Australian Stock Exchange Corporate Governance Council (2003). Principles of Good Corporate Governance and Best Practice Recommendations, Retrieved January 5, 2009, from http://www.asx.com.au/documents/about/principles-and-recommendations- march-2003.pdf. 
Brown, R., \& Gorgens, T. (2009) Corporate Governance and Financial Performance in an Australian Context. Retrieved June 22, 2009, from http://archive.treasury.gov.au/contentitem.asp?NavId=049\&ContentID=1495.

Cadbury, A. (1992). The Committee on the Financial Aspects of Corporate Governance, London: Gee and Company.

Coffee, J.C. (2002). The impact of cross-listing and stock market competition of international corporate governance. Columbia Law Review, 102, 1757-1831. http://dx.doi.org/10.2307/1123661

D'Aquila, J.M. (2004). Tallying the cost of the Sarbanes-Oxley Act', The CPA Journal. Retrieved April 15, 2012, from http://www.nysscpa.org/cpajournal/2004/1104/perspectives/p6.htm.

DeFond, M.L., \& Jiambhalvo, J. (1991). Incidence and circumstances of accounting errors. The Accounting Review, 66(3), 643-655.

Dominquez- Almendros, S, Benitez-Parejo, N \& Gonzalez-Ramirez, AR 2011, 'Logistic Regression Models. Retrieved January 12, 2012, from http://www.elsevier.es/sites/default/files/elsevier/eop/S0301-0546(11)00201-1.pdf.

Du-Plessis, J., McConvill, J., \& Bagaric, M. (2005) Principle of Contemporary Corporate Governance, Cambridge: Cambridge University Press. http://dx.doi.org/10.1017/CBO9780511813481

Fleming, G. (2003). Corporate governance in Australia. Agenda, 10(3), 95-212.

Hamilton, K. (2003). 'If Not, Why Not? in conversation with Karen Hamilton, Chairperson, ASX Corporate Governance Council. Keeping Good Companies.

Implementation Review Group (IRG). (2004). Principles of Good Corporate Governance and Best Practice Recommendations. Sydney: ASX Corporate Governance Council.

Jensen, M.C. (1986). Agency costs of free cash flow, corporate finance and takeovers. American Economic Review, 72(2), 323-329.

KPMG (2004). Early Reporting Trends: A Survey of Early Reporting Trends Under the ASX Corporate Governance Council Guidelines. Melbourne: KPMG.

KPMG (2005). Reporting Against ASX Corporate Governance Council Guidelines: A shift Towards Performance, Melbourne: KPMG.

Krishnan, J., Rama, D., \& Zhang, Y. (2008). Costs to comply with SOX Section 404. Auditing: A Journal of Theory and Practice, 27(1), 169-186. http://dx.doi.org/10.2308/aud.2008.27.1.169

Kristjanson, P., Krishna, A., Radeny, M., Kuan, J., Quilca, G., \& Sanchez-Urrelo, A. (2007). Dynamic Poverty Processes and the Role of Livestock in Peru, PPLPI Working Papers No. 39. Retrieved March 9, 2012, from http://www.fao.org/Ag/againfo/programmes/en/pplpi/docarc/wp39.pdf.

La Porta, R., Lopez-de-Silanes, F., Shleifer, A., \& Vishny, R.W. (2002). Investor protection and corporate valuation', Journal of Finance, 7(3), 1147-1170. http://dx.doi.org/10.1111/1540-6261.00457

Lumsden, A. (2004). The role and responsibilities of directors on board subcommittees. Retrieved July 1, 2014, from http://www.law.unimelb.edu.au/files/dmfile/roleanddirectors1.pdf.

MacNeil, I., \& Li, X. (2006). Comply or explain: market discipline and non-compliance with the combined code. Corporate Governance: An International Review, 14(5), 486-496. http://dx.doi.org/10.1111/j.1467-8683.2006.00524.x

McMullen D.A. (1996). Audit committee performance: an investigation of the consequences of associated with audit committees. A Journal of Practice and Theory, 15(1), 87-103.

Nedelchev, M. (2013). Good practice in corporate governance. Internal Journal of Business Administration, 4(6), $75-81$.

Pallant, J. (2007) SPSS Survival Manual: A Step by Step Guide to Data Analysis Using SPSS for Windows (3 ${ }^{\text {rd }}$ ed.). Maidenhead Berkshire: McGraw-Hills Education.

PricewaterhouseCoppers. (2012). Switzerland: proposal affecting executive compensation. Retrieved April 27, 2014, from, https://www.pwc.ch/user_content/editor/files/publ_hrs/pwc_news_alert_2012-10a_e.pdf.

Seidl, D., Sanderson, P., \& Roberts, J. (2009). Applying 'comply-or-explain': conformance with codes of corporate governance in the UK and Germany, Working Paper No. 389. Retrieved May 30, 2010, from http://www.cbr.cam.ac.uk/pdf/WP389.pdf. 
Steeno, A. (2006). Note: corporate governance: economic analysis of a 'comply or explain' approach. Stanford Journal of Law, Business \& Finance, 11(2), 387-408.

Wang, D., \& Ong, C.H. (2005). Board structure, process and performance: evidence from public-listed companies in Singapore. Corporate Governance: An International Review, 13(2), $277-290$. http://dx.doi.org/10.1111/j.1467-8683.2005.00422.x

Zadkovich, J. (2007). Mandatory requirements, voluntary rules and 'please explain': a corporate governance quagmire. Deakin Law Review, 12(2), 182-213.

\section{Notes}

Note 1. The ASX governance principles were introduced in 2003 and underwent a major review in 2007.

Note 2. Multicollinearity was tested for by regressing each of the predictor variables against the others. The relatively small correlation coefficients rejected the condition of unacceptably high multicollinearity. 